\title{
原著
}

\section{保育所における蟯虫感染の涴学的开究 (II)}

Epidemiological Studies on Enterobiasis carried out in One of the Public Nursery (II)

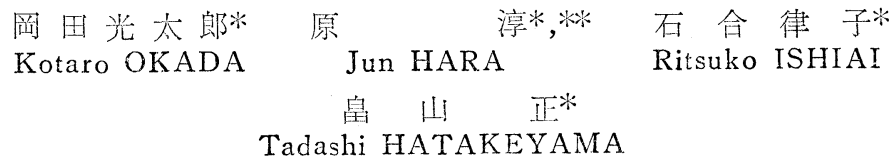

\section{緒言}

篗者らは，先に埼玉県静村 1) 扎よび干葉県佐弇书，

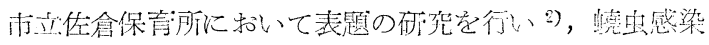

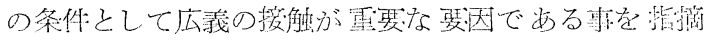

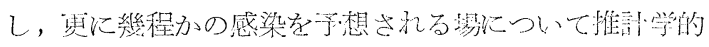

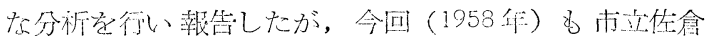

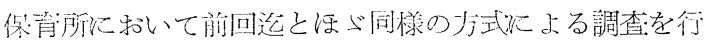
なつたので, 前回运の結果と比較梌酎して赫皆する・調

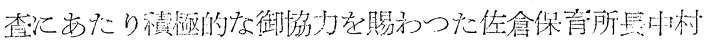

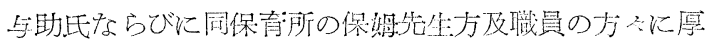
く感謝する。

\section{調查方法と調查対称}

調查打法は前回迄と同様である。即ら门1.9糎の七口 テーブを貼付したスシイド年ンをを園罗家族全負に配在

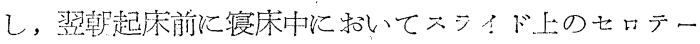
プそはがし肛門を中心として㙋付し，直らに再び前のよ うにスフィイ゙に貼り，これを検鏡する方法により調查沉 た・同時に調查:用紙による資間もあわせて行，家㵀擭 成・幼罗の世話・赛窒之居間の広さ・下着の取り換光頻 度・入浴の頻度・疾病の有舆・その他等について, それ

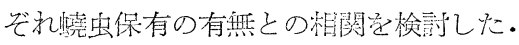

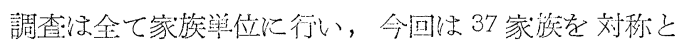
乙, 回收不能7 家族学除き,30家族（回集率 $81.9 \%$ ) 137 名について調查結果を得た。充分な数とはいえない

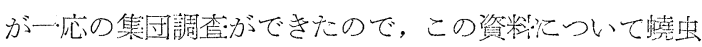

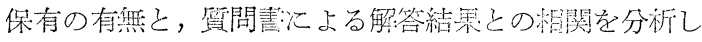

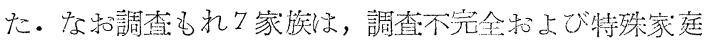

\footnotetext{
* 做天堂大学生物学教空

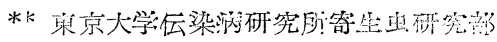
1959 年7月7日受付
}

\section{による調烃:不能家莛である・}

\section{蛙虫保有率}

乡回の一回の検肛検烃沈より，137名中49名（35.76 \%) 飞期点保有者を見た・前回の佐倉保青所の結果, 158 名中 83 苔 $(52.5 \%$ ) 飞浪及ばないが，静村(昭和 31 年)1１77名中 46 名 $(26.0 \%)$ 上り高率であつた。これ 以第一回調查: (昭和 32 年) 2)より蛙虫駆虫の啓蒙運動 を行ているので先の結柴と考えられる・

\section{A. 州颔に見た保有率}

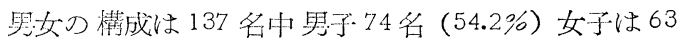
名（45.8\%）であつた。性号比見た蛙虫保有率は表1に 示した通りで，男子 74 名中 27 名 (36.5\%) 女子 63 名 中 22 名 $(34.9 \%)$ であつた。前回迄之同様蟯虫感染に

表 1 性别蛙出保有数

\begin{tabular}{|c|c|c|c|c|}
\hline & 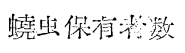 & 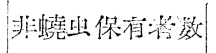 & 合 & 訪 \\
\hline 男于 & $27 \quad(55.1)$ & $48 \quad(54.5)$ & 75 & $(54.74)$ \\
\hline 灰于 & $22 \quad(44.9)$ & $40 \quad(45.5)$ & 62 & $(45.25)$ \\
\hline 合 & 49 (35.76) & $88 \quad(64.24)$ & 137 & $(100.0)$ \\
\hline
\end{tabular}

ついて界女間に有意な差注認められない，但し年令別に

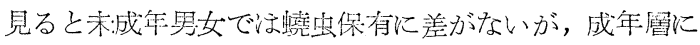
和いて明らかに女子に保有者が多いの後述の如く子供 との接触に要因が市るものと考㿝られ，必らずしも本留 的なものではないと思われる。

B. 年令別保有率

零才より19才迄，はじぬは 5 年，20才より10年の 区間心隔により分けた各年令層に打ける憢虫保有の有無 は表 2 に示した通りである・明らかに年令㢞による蟯虫 保有の差が見られるが，一栏性の検定の結果でも $0.1 \%$ 
表 2 年命别・性则蟯出保凊者数

\begin{tabular}{|c|c|c|c|c|c|c|c|}
\hline \multirow{2}{*}{ 特令区分 } & \multicolumn{3}{|c|}{ 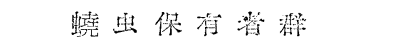 } & \multicolumn{3}{|c|}{ 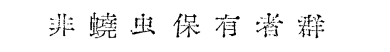 } & \multirow{2}{*}{ 総 計 } \\
\hline & 男 & 女 & 拿 计 & 男 & 女 & 合 谟 & \\
\hline $0 \sim 4$ & $\begin{array}{c}5 \\
(36.7)\end{array}$ & $\begin{array}{c}5 \\
(55.6)\end{array}$ & $\begin{array}{c}10 \\
(43.5)\end{array}$ & 9 & 4 & 13 & $\begin{array}{c}23 \\
(16.8)\end{array}$ \\
\hline $5 \sim 9$ & $\begin{array}{c}8 \\
(42.1)\end{array}$ & $\begin{array}{c}7 \\
(70.0)\end{array}$ & $\begin{array}{l}15 \\
(51.7)\end{array}$ & 11 & 3 & 14 & $\begin{array}{c}29 \\
(21.2)\end{array}$ \\
\hline $10 \sim 14$ & $\begin{array}{c}11 \\
(88.6)\end{array}$ & $\begin{array}{c}3 \\
(33.3)\end{array}$ & $\begin{array}{l}14 \\
(60.9)\end{array}$ & 3 & 6 & 9 & $\begin{array}{c}23 \\
(16.8)\end{array}$ \\
\hline $15 \sim 19$ & $\begin{array}{c}0 \\
(0.0)\end{array}$ & $\begin{array}{c}0 \\
(0.0)\end{array}$ & $\begin{array}{c}0 \\
(0.0)\end{array}$ & 2 & 3 & 5 & $\begin{array}{c}5 \\
(3.6)\end{array}$ \\
\hline $20 \sim 29$ & $\begin{array}{c}0 \\
(0.0)\end{array}$ & $\begin{array}{c}1 \\
(11.1)\end{array}$ & $\begin{array}{c}1 \\
(7.7)\end{array}$ & 4 & 8 & 12 & $\begin{array}{c}13 \\
(9.5)\end{array}$ \\
\hline $30 \sim 39$ & $\begin{array}{c}1 \\
(7.7)\end{array}$ & $\begin{array}{c}3 \\
(23.1)\end{array}$ & $\begin{array}{c}4 \\
(15.4)\end{array}$ & 12 & 10 & 22 & $\begin{array}{c}26 \\
(19.0)\end{array}$ \\
\hline $40 \sim 49$ & $\begin{array}{c}1 \\
(25.0)\end{array}$ & $\begin{array}{c}3 \\
(42.8)\end{array}$ & $\begin{array}{c}4 \\
(36.4)\end{array}$ & 3 & 4 & 7 & $\begin{array}{c}11 \\
(8.0)\end{array}$ \\
\hline $50 \sim 59$ & $\begin{array}{c}1 \\
(50.0)\end{array}$ & $\begin{array}{c}0 \\
(0.0)\end{array}$ & $\begin{array}{c}1 \\
(50.0)\end{array}$ & 1 & 0 & 1 & $\begin{array}{c}2 \\
(1.5)\end{array}$ \\
\hline $60 \sim 69$ & $\begin{array}{c}0 \\
(0.0)\end{array}$ & $\begin{array}{c}0 \\
(0.0)\end{array}$ & $\begin{array}{c}0 \\
(0.0)\end{array}$ & 1 & 2 & 3 & $\begin{array}{c}3 \\
(2.2)\end{array}$ \\
\hline $70 \sim 79$ & $\begin{array}{c}0 \\
(0.0)\end{array}$ & $\begin{array}{c}0 \\
(0.0)\end{array}$ & $\begin{array}{l}0 \\
(0.0)\end{array}$ & 1 & 1 & 2 & $\begin{array}{c}2 \\
(1.5)\end{array}$ \\
\hline 合 䛎 & $\begin{array}{c}27 \\
(36.5)\end{array}$ & $\begin{array}{c}22 \\
(34.9)\end{array}$ & $\begin{array}{c}49 \\
(35.8)\end{array}$ & $\begin{array}{c}47 \\
(63.5)\end{array}$ & $\begin{array}{c}41 \\
(65.1)\end{array}$ & $\begin{array}{c}88 \\
(64.2)\end{array}$ & $\begin{array}{c}137 \\
(100.1)\end{array}$ \\
\hline
\end{tabular}

以下の危険率で有意な差が認められる・この有意差は零 寸より15 才运に高い保有率が示され，15才より39才 の間に低い保有率が示されているためである・蟯虫保有 率を年令別に見ると今回迄の全ての結果に和いて，零才 から15 才迄は年毎に增加し，15 才より20 才に䄧いて 急激に減じ，再び漸增して 40 才〜49 才に再び低い峰を もつよらな推移が認められる・これは他の蠕虫とは明ら かに違つた感染罣（群）の推移の特長であり，蟯虫特暴 のものと考光られ，この点からも蟯虫感染経路の特長が らかぶわれる・またこのよらな推移を示すことは，零才 から15才汽の保有率の峰が，日裳のあそど，または保 有所・幼稚園・学校と次第に妙巟同志が互いに接触する

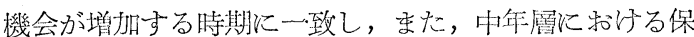

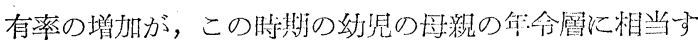
ることは，蟯虫感染虫他の蠕虫と異なり，接保による感 染が央要であることを示しているものと思われる。

\section{蟯虫保有率之家族集積性}

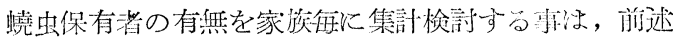
の如く憢虫感染は相互の接触が冓要な伝播の機会と考え られる事加ら意味のある事である。な特，この他厄学校
表 3 蟯出感染の家族集䅡性!゙ついて

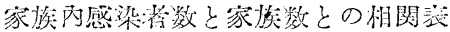

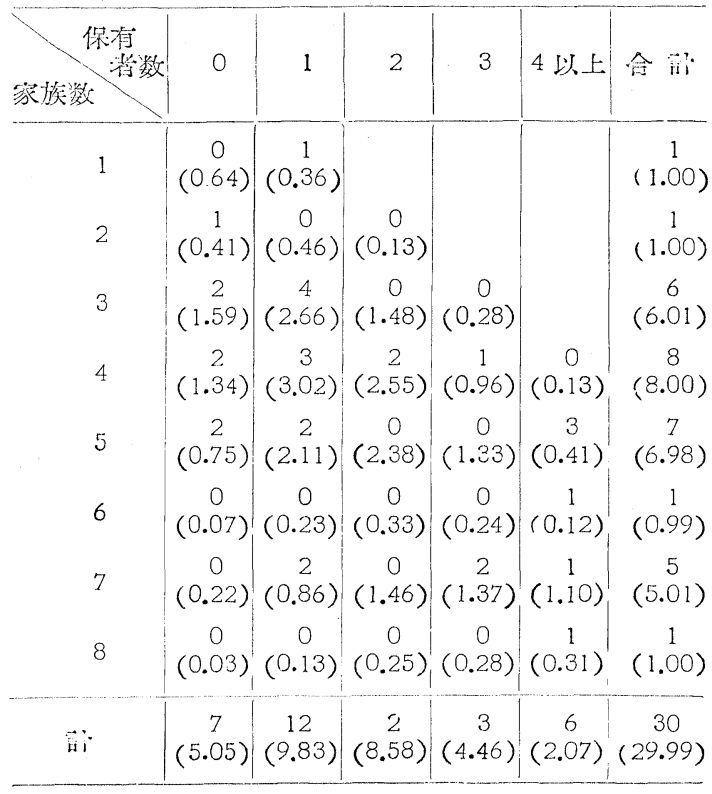

（）內は理論値 $\{\mathrm{p}=0.3576 \mathrm{q}=0.6424\}$ として 
表 4 家族內箱䅡性についての検討

\begin{tabular}{|c|c|c|c|c|c|c|}
\hline 保有者数 & 0 & 1 & 2 & 3 & 4 以上 & 合 触 \\
\hline 観測戶数 & 7 & 12 & 2 & 3 & 6 & 30 \\
\hline 理論戶数 & 5.05 & 9.83 & 8.58 & 4.46 & 2.07 & 29.99 \\
\hline 偏美 & +1.95 & +2.17 & -6.58 & -1.46 & +3.58 & +0.06 \\
\hline$x^{2}$ & 0.75 & 0.46 & 5.05 & 0.48 & 7.65 & 14.39 \\
\hline
\end{tabular}

・保青:所・幼稚園も同様の意㸬で重要な感染の場である

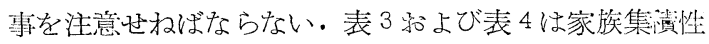
について, 二項分布にしたがい一様な感染にさらされて いるものとして覓出した理論值と実測值との比較を表わ すものである・この間の一様性の検定を行つた結果は表 4 亿示す如く，危険率 $0.1 \%$ 以下で明らかな有急差があ る事を示し，同時に家族集樍性のある事をあらわしてい る・家族内の集樍性を更に詳細に検誩するために母と 子・父と子・夫と妻・兄弟の間について相関を検べて見 ると次の通りである・

\section{A. 母之子の関連}

幼巟斯に和いて極端に高い蟯虫保有率走示す事が明ら かであり，摆触が感染の再大な要因であると仮定した場 合，家族内に扣いて最も幻児亡接触の機会の大きい母之

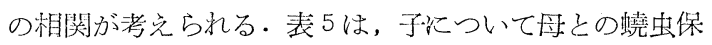
有の有璂を示した表である. 子供をるつ年令の母親の蛄 虫保有率ば拉よそ23\%であるが，子供が蟯虫保有者で ある場合の母親の感染率は $51.8 \%$ で高い值を示してい る・これについて無相関の検定を行うと，危除率は1\% 以下であるので，母と子との間に揖いて感染に相関があ るという事ができる・

表 5 村と于との睢出保有の相関

\begin{tabular}{|c|c|c|c|c|}
\hline 性 子 & 保直孝数 & 非保凊潘数 & 会 & 邻 \\
\hline 保㤫者数 & $\begin{array}{c}14 \\
(51.8)\end{array}$ & 13 & & 27 \\
\hline 非保准教数 & $\begin{array}{c}23 \\
(41.1)\end{array}$ & 33 & & 56 \\
\hline 合 & $\begin{array}{c}37 \\
(44.6)\end{array}$ & 46 & & 83 \\
\hline
\end{tabular}

\section{（）內は百分比}

B. 父と子の関連

前項と同様の事を父の堭合について検詰してみると， 表6に示した如くで相関があるといら事はできない，第 1 回の調查では相関が認められているにもかつわらず今
表 6 父と子との蝰出保有の相関

\begin{tabular}{|c|c|c|c|c|}
\hline 父 子 & 保有挣数 & 非保有者数 & 合 & 草 \\
\hline 保有落数 & $\begin{array}{c}4 \\
(40.0)\end{array}$ & 6 & & 10 \\
\hline 非保有福数 & $\begin{array}{c}25 \\
(42.4)\end{array}$ & 34 & & 59 \\
\hline 合 & $\begin{array}{c}29 \\
(42.0)\end{array}$ & 40 & & 69 \\
\hline
\end{tabular}

$$
\text { （）阿泬百分比 }
$$

回の調查に和いて相関が認められなかつた原因について は明らかでないが，少なくとも佐倉保青所奣童の家庭に 打いて父親は寿親に比較して，幼兒との接触の機会が少 ない事は考えられる・また佐倉保青:所罗童の家庭のみに 限らず，一般に父親は母親に比べて幼見との接触は極め て少ないといえよう。

\section{C. 夫と毒との関連}

調柾:例が極めて少ないので無相関の検定を行らのは無 暴といえるが，検定の結果では無相関，すなわち夫と妻 との間に蟯虫保有率の相関がない事になつた（表7）。

表 7 夫と膟との畦出保有の相関

\begin{tabular}{|c|c|c|c|c|}
\hline 妻 夫 & 保静消数 & 非保有省数 & 合 & 計 \\
\hline 㛊有渚数 & $\begin{array}{c}1 \\
(50.0)\end{array}$ & 1 & & 2 \\
\hline 非保有者数 & $\begin{array}{c}5 \\
(26.3)\end{array}$ & 14 & & 19 \\
\hline 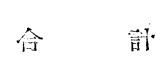 & $\begin{array}{c}6 \\
(28.6)\end{array}$ & 15 & & 21 \\
\hline
\end{tabular}

たざし例数が少ないのでこの結果からは何とも判断しか ねると考えられる・

D. 圥弟姉妹の間の関連

幼罗の間の感染が非常に濃厭である牙は，任令別蟯虫 保有率に既に見た通りであるが，家族内に括いて，兄弟 の間に感染の相関を求める事は, その感染の場が家庭に あるか否かを知る上に重琶:であるので，今回の調查結果 から検討して夕外（表8). 兄弟の間に相互感染の機会 が特になく一様な感染の機会にさらされているとして求 めた理論值と観測值との間に和将る適合の度合を検䚯し て見ると，危険率 5\%〜10\%で特に有意な差が認められ ないが，有意差がないと認めるには余りにもくいらがい が大きすぎる・とくに非感染见弟群と感染见俤群との間 の一様性の検定の結果で゙明らかな差䀧が認められるの で，危険率の部容限㥰を少し大き好とれば，柏関があ 
表 $8 \cdot 1$ 兄弟 の相 関

\begin{tabular}{|c|c|c|c|c|c|c|c|}
\hline $\begin{array}{l}\text { 兄 } \\
\text { 有 } \\
\text { 卦 } \\
\text { 数 }\end{array}$ & 1 & 2 & 3 & 4 & 5 & 6 & 謨 \\
\hline 0 & $\begin{array}{c}1 \\
(1.668)\end{array}$ & $\begin{array}{c}4 \\
(2.178)\end{array}$ & $\begin{array}{c}2 \\
(0.438)\end{array}$ & $\begin{array}{c}0 \\
(0.195)\end{array}$ & $\begin{array}{c}1 \\
(0.052)\end{array}$ & $\begin{array}{c}0 \\
(0.030)\end{array}$ & $\begin{array}{c}8 \\
(4.561)\end{array}$ \\
\hline 1 & $\begin{array}{c}2 \\
(1.332)\end{array}$ & $\begin{array}{c}6 \\
(5.431)\end{array}$ & $\begin{array}{c}1 \\
(1.643)\end{array}$ & $\begin{array}{c}1 \\
(0.973)\end{array}$ & $\begin{array}{c}0 \\
(0.324)\end{array}$ & $\begin{array}{c}0 \\
(0.142)\end{array}$ & $\begin{array}{c}10 \\
(9.845)\end{array}$ \\
\hline 2 & & $\begin{array}{c}1 \\
(3.339)\end{array}$ & $\begin{array}{c}2 \\
(2.057)\end{array}$ & $\begin{array}{c}0 \\
(1.826)\end{array}$ & $\begin{array}{c}1 \\
(0.811)\end{array}$ & $\begin{array}{c}0 \\
(0.282)\end{array}$ & $\begin{array}{c}4 \\
(8.375)\end{array}$ \\
\hline 3 & & & $\begin{array}{c}0 \\
(0.860)\end{array}$ & $\begin{array}{c}3 \\
(1.527)\end{array}$ & $\begin{array}{c}0 \\
(1.015)\end{array}$ & $\begin{array}{c}1 \\
(0.301)\end{array}$ & $\begin{array}{c}4 \\
(3.703)\end{array}$ \\
\hline 4 & & & & $\begin{array}{c}1 \\
(0.478)\end{array}$ & $\begin{array}{c}1 \\
(0.637)\end{array}$ & $\begin{array}{c}0 \\
(0.180)\end{array}$ & $\begin{array}{c}2 \\
(1.295)\end{array}$ \\
\hline \multirow[t]{2}{*}{5} & & & & & $\begin{array}{c}0 \\
(0.160)\end{array}$ & $\begin{array}{c}0 \\
(0.065)\end{array}$ & $\begin{array}{c}0 \\
(0.225)\end{array}$ \\
\hline & 3 & 11 & 5 & 5 & $\begin{array}{c}3 \\
(2.999)\end{array}$ & $\left(\begin{array}{c}1 \\
(1.000)\end{array}\right.$ & $\begin{array}{c}28 \\
(28.004)\end{array}$ \\
\hline
\end{tabular}

表 $8 \cdot 2$ 兄弟の相閣についでの检討

\begin{tabular}{|c|c|c|c|c|c|c|}
\hline \multicolumn{2}{|c|}{ 蛙堯出保有滥数 } & 0 & 1. & 2 & 3 以上 & $\mathrm{it}^{\circ}$ \\
\hline 䶡 & 度 & 8 & 10 & 4 & 6 & 28 \\
\hline 浬 論 & 值 & 4.56 & 9.85 & 8.38 & 5.22 & 28.01 \\
\hline$\chi^{2}$ & & 2.51 & 0.04 & 2.31 & 0.12 & 4.94 \\
\hline
\end{tabular}

ると考えても差支えないものと思う・

\section{日常の生活との相関}

翼問紙により，日常の着衣，とくに下着の形状とその

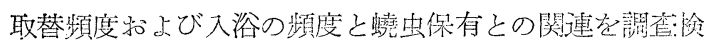

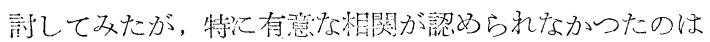
前回迄と同様である.下視の取換頻度は每日丁至 1 週间

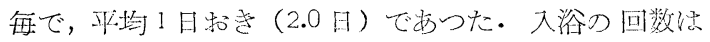
每日乃至 5 日以上に 1 回で, 壮 2.26 日年ですつた. すなわちこの範围は通常の頻度に近いと考えてよい值で

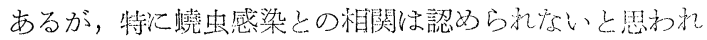

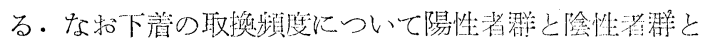

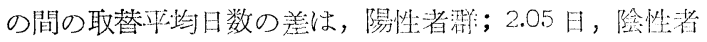

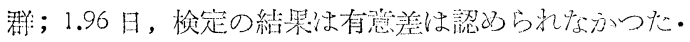

\section{便通の頻度・便の性状尤よび肛門周思の 䭷溹感亡の相関}

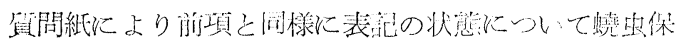
有の有無とり相関を检べた・便通の頻度では，蛙虫保有

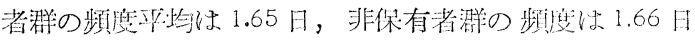

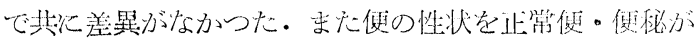

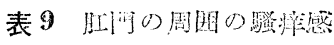

\begin{tabular}{|c|c|c|c|}
\hline & 蟯些保有的 & 非雇保教 & 合 \\
\hline 空 & $\begin{array}{l}34 \\
(34.7)\end{array}$ & 64 & 98 \\
\hline$\dot{\omega}$ & $\begin{array}{c}13 \\
(46.4)\end{array}$ & 15 & 28 \\
\hline わわら火 & 0 & 1 & 1 \\
\hline 今 & 47 & 80 & 127 \\
\hline
\end{tabular}

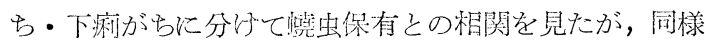

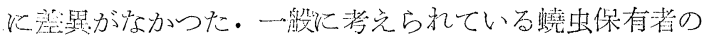

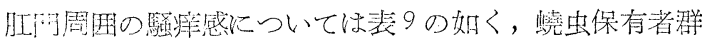

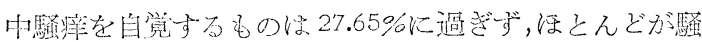

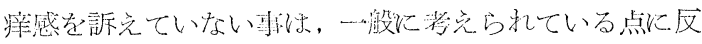

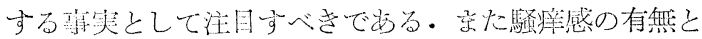

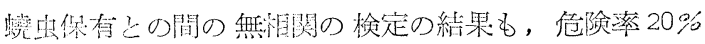

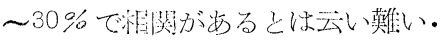

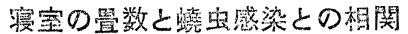

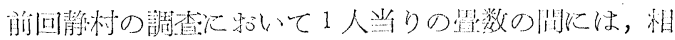

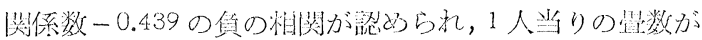

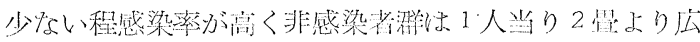

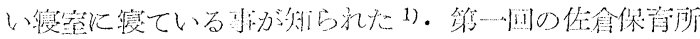

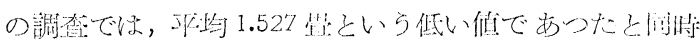

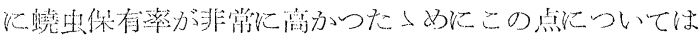

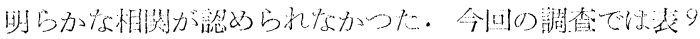


表 10 スコッチテープ法による蛙出保有検登の检墛

\begin{tabular}{|c|c|c|c|c|c|c|c|c|c|c|c|}
\hline & $\begin{array}{l}\text { 禁 } \\
\text { 于 }\end{array}$ & $\begin{array}{l}\text { 洋 } \\
\text { 子 }\end{array}$ & $\begin{array}{l}\text { 燨 } \\
\text { 次 }\end{array}$ & $\begin{array}{l}\text { 骝 } \\
\text { 美 }\end{array}$ & 互 & $\begin{array}{l}\text { 喜 } \\
\text { 子 }\end{array}$ & $\begin{array}{l}\text { 桂 } \\
\text { 子 }\end{array}$ & 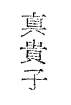 & $\begin{array}{l}\text { 光 } \\
\text { 雄 }\end{array}$ & $\begin{array}{l}\text { 冹 } \\
\text { 帒 } \\
\end{array}$ & $\begin{array}{l}\text { 檢 } \\
\text { 胳 } \\
\text { 率 }\end{array}$ \\
\hline 1 & $H$ & $t$ & $t$ & $H$ & $\mathrm{HH}$ & it & $H$ & - & + & & 88.9 \\
\hline 2 & $H$ & & it & $H$ & + & $H$ & $H$ & $H$ & $t$ & $H$ & 100.0 \\
\hline 3 & + & +4 & 4 & $H$ & 洲 & $H$ & H & $\mathrm{HH}$ & $H$ & - & 90.0 \\
\hline 4 & & & & & & & & & & & \\
\hline 5 & + & & $H$ & + & Ht & + & $H$ & $H$ & + & $t$ & 100.0 \\
\hline 6 & $H$ & & $H$ & itt & & & & - & & $H$ & 80.0 \\
\hline 7 & - & & - & - & & & & $+t$ & & $t$ & 40.0 \\
\hline 8 & HH & + & + & & + & + & $H$ & - & & & 85.7 \\
\hline 9 & - & & + & $H$ & & & & & & +4 & 75.0 \\
\hline 10 & $H$ & + & - & $H$ & & & - & - & - & $m$ & 50.0 \\
\hline 検活棌 & 77.8 & 100.0 & 80.9 & 77.8 & 100.0 & 100.0 & 83.3 & 50.0 & 80.0 & 85.7 & 83.6 \\
\hline
\end{tabular}

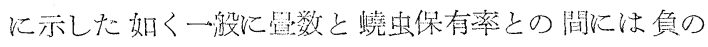
㮩関が認好られ(相関係数： - 0.435)，一㥞性の検定の 結果孔危除摔 $1 \%$ 以下で明らか炕有譩差が認邓られた。

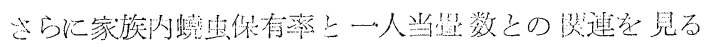

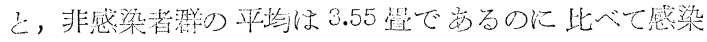

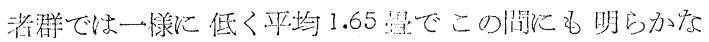

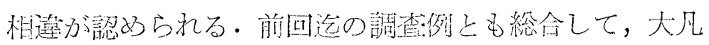

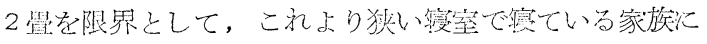

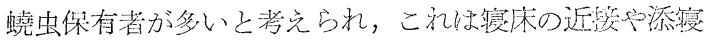

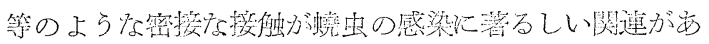
ると推测される・

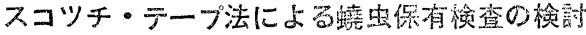

前回の報告の結果を追試するた奴，今回る明らが 陽性（蟯虫保有者）の保銷所兒意 10 名走刘称として, 10日間の間に 5〜10回の検肚をスコッテ・テープ法に 上り备自行い，その梌出率を検討した・表10经艺の結

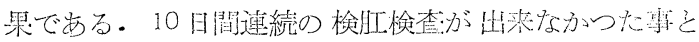
第4日目の結果が不明で西る点は遗憾で西るが，正抣

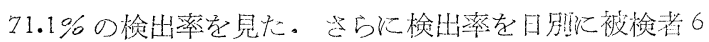
名以上を得た6 日間化ついて見ると $85.5 \%$ で其炕 $80 \%$ 飞近い検出率であると教党られる。仮り飞 1 回の裣出率 を $80 \%$ として $95 \%$ 以上の検出率を琵求するならば，少 なくとも3 回の検肛を必要々する・な和をた，検出率が 80\%程度であるならば, 优の虫卵椧查と比較して、午

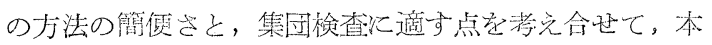
法は捨て難い勝れた技法とい方よう。

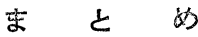

林・原らが沼和 31 年静村火执いて行つた調查絬果火

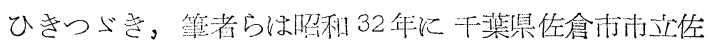
倉保青所比抒いて蟯虫感染経路の疫学的研究夌行つた

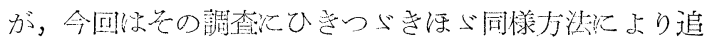

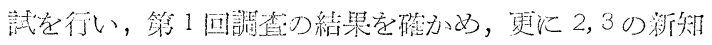
見堂得た。

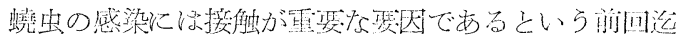

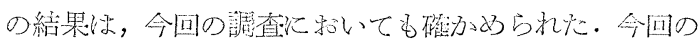
絬果の概要添次の通りである。

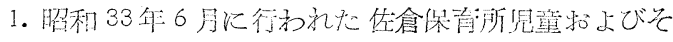
の芜族，30 家族 137 舀について一回の檢师を行い，49

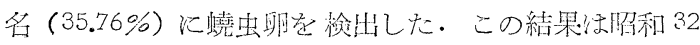

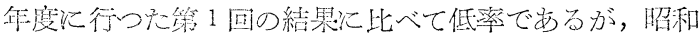
31 年度の静村の繥果江比べてな赫滈率であつた。

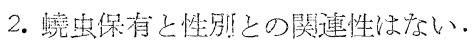

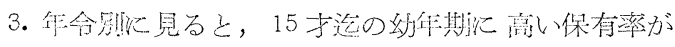

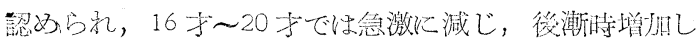
て 30 才〜50才於いて保有率の第2 の峰が認められ る・この年代では女子の保有者が多い。

4. 家族集樍性は可成り䫓著化認められ，母と子との

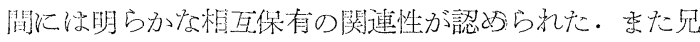

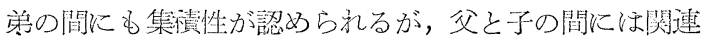
が認められなかった。

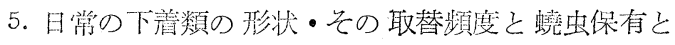
の租閶は認められない, 宗九入浴頻度之蟯虫保有之の相 関も認好ら机ない。

6. 便通の頻度・偭の性状飞ついて蛙虫保有之の相関

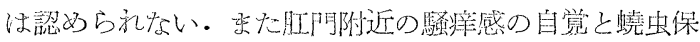

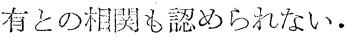

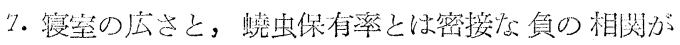


あり，一般に狭い程蟯虫感染にさらされ易い、今調查:で は，感染者群は 2 畳以下 (一人当平均畺数) の場合に多 く, 非感染者群との平均盢数の柏違は顕著:である.

8. 10 人の蟯虫保有児童を対称として 10 日間に 5 ～10 回の検肍を行い, セロテーブ法による蟯蝍検出率を検 討した結果，今回は活ぶ 80\%の検出率を見たが，95\% 以上の検出率を求めるには少くとも連続 3 回以上の検肛 そ必要とする・

9. 以上の結果加ら，前回运の結果恃更に磪認せられ， 蟯虫感染には，同居・同室等の広義の按触感染が䨘大な 要因であることがうから゙われる・特に狭い寝室に寝る家 族や，学令斯の罗童倍高感染率が認められ，更た著る しい家族集蔶性が認められることは，日常生活炕括汀る 相互の接触の 疎密と蟯虫感染が 比例するかの如くであ り, 接触の重要性を裏付けている・

（本研究心゙順天堂大学々內研究窝による。）
（㗹和 34 年 2 月順天堂医学会に琶旨講演）

\section{参考 文 献}

1) 林竝生, 原淳, 本木敬二，简田敦德：埼玉県の 1 モデル衛生利, 静利における蟯虫感染の将学的研 究，順医誌，3(3)，1957。

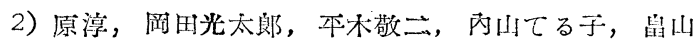
正：保奇所における蟯虫感染の没学的研究 (I ), 順医誌， 2 (4), 1958.

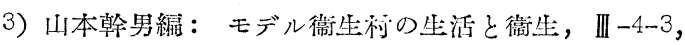
p. $233,1957$.

4）村”重武次：蟯虫検查成績，特に゙㖨人に於ける感染 状況, 笴生虫学雑誌, 6 (5), p. 84.

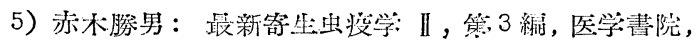
果京, 1951 .

\section{Summery}

In the previous paper, the authers studied on the Enterobiasis in the public nursery and mentioned of the individual contact in a broad sense might be the most important cause for infection.

In the present paper they discribed in the results of the survey carried out in the Sakura public nursery, Chiba pref., in June, 1958, using similar method as the previous survey and they could ascertain by the results as the infection of Enterobiasis ought to the individual contact in a broad sense again.

1) Among 49 (35.76\%) persons out of 139 belonging 30 families examined, pinworm eggs were detected. Correlation of the infection between male and female were not obserbed.

2) High rate of infection were obserbed among children belonged in lower than 15 years old and the rate showed the tendency of increase gradually. Further more in middle aged persons in $30 \sim 40$ years old high rates of infection were obserbed considerably, especially in women in these ages showed more heavy infection rate than man.

3) The tendency of familial aggregation of infection was very conspicuous, and a correlation was showed remarkably between infected children and their mother and between their brothers and sisters, but no significant correlation between infected children and their fathers.

4) No correlation were obserbed between the infection rates and the frequency of bathing or changing underwears. Further more only 27.7 percents persons in all infected persons apealed the itch of anal part.

5) Negative correlation between the space of the bed room and the rate of infection were showed. Higher infection rate found in the families lived in smaller spaces than the average number of the tatami, two tatami per person, in the bed room.

6) The results to examine perianal part of the infected children $5 \sim 10$ times in 10 days showed about $80 \%$ of confidence of the scotch cellulose tape swab method. For that reason if we expect to $95 \%$ confidence of result, we may have to try for three days running at least.

Department of Biology, Juntendo University, School of Education.

Department of Parasitology, Institute for Icfections Diseases, University of Tokyo. 